\title{
REMINISCÊNCIAS DO REGIME MILITAR BRASILEIRO E OS CONTEMPORÂNEOS ECOS POR UMA "INTERVENÇÃO MILITAR CONSTITUCIONAL": PONTOS DE TENSÃO E (IM)POSSIBILIDADES
}

REMINISCENCES OF THE BRAZILIAN MILITARY SYSTEM AND CONTEMPORARY CRY FOR "INTERVENTION CONSTITUTIONAL MILITARY": POINTS OF TENSION AND

(IM)POSSIBILITIES

Tayson Ribeiro TELES ${ }^{1}$

ISSUE DOI: $10.21207 / 1983.4225 .616$

\begin{abstract}
RESUMO
Desde o início do século XXI os brasileiros têm sido surpreendidos com o desvelamento de comuns e constantes práticas corruptivas e criminosas da maioria das autoridades constituídas e investidas de poder público, notadamente na esfera federal. Os políticos e demais autoridades estatais agem in fraudem legis e depois de pegos descaradamente negam ou delatam para obter vantagens. De fronte a esta calamidade, certa parcela do povo cogita um retorno dos militares ao poder, como ocorreu entre 1964 e 1985. Pensar sobre estas questões, a partir de breve rememoração do que foi o mais recente "governo" militar brasileiro, e analisar os dispositivos legais atuais que versam sobre o tema: esse é nosso objetivo neste artigo. A metodologia é a exploração bibliográfica revisional. As conclusões indicam que no atual desenvolvimento democrático pátrio, em termos morais e legais, principalmente constitucionais, é impossível uma intervenção militar de caráter nacional que tenha o fito de
\end{abstract}

\footnotetext{
${ }^{1}$ Mestre em Linguagem e Identidade (Cultura e Sociedade) pela Universidade Federal do Acre - UFAC (2016). Especialista em Gestão de Políticas Públicas pela Universidade Federal de Ouro Preto - Minas Gerais (2016). Graduado em Finanças pela UniSEB, de Ribeirão Preto - SP (2013). Licenciado em Matemática pelo Ceuclar - SP (2015). Bacharel em Direito pela UFAC (2017). Docente EBTT, área Economia, do Instituto Federal do Acre - IFAC. http://orcid.org/0000-0003-1309-8708.
} 
"desinstalar a desordem corruptiva" da nação. Por outro lado, em termos práticos, infelizmente, é sempre factível um golpe de Estado, civil ou militar, bastando apenas que alguém o queira fazer e tenha força para tal.

Palavras-chave: "Governo" militar brasileiro (1964-1985). Século XXI. Corrupção. "Intervenção militar constitucional". (Im)possibilidade.

\begin{abstract}
Since the beginning of the twenty-first century Brazilians have been surprised by the unveiling of common and constant corruptive and criminal practices of most of the authorities constituted and invested with public power, notably at the federal level. Politicians and other state authorities act in fraudem legis and after being shamelessly deny or betray to gain advantages. Faced with this calamity, a certain portion of the people considered a return of the military to power, as occurred between 1964 and 1985. Thinking about these issues, starting with a brief remembrance of what was the most recent Brazilian military "government", and analyzing the current legal devices dealing with the topic: this is our goal in this article. The methodology is the revisionary bibliographic exploration. The conclusions indicate that in the current democratic development of the country, in moral and legal terms, mainly constitutional, it is impossible a military intervention of national character that has the aim of "uninstalling the corrupting disorder" of the nation. On the other hand, in practical terms, unfortunately, a coup d'etat, civil or military, is always feasible, if only someone wants to do it and has the strength to do so.
\end{abstract}

Keywords: Brazilian "Government" Military (1964-1985). XXI century. Corruption. "Constitutional military intervention". (Impossibility.

\title{
INTRODUÇÃO
}

\begin{abstract}
"Desde que a ex-presidente cassada, Dilma Rousseff, foi reeleita, em 2014, que os opositores do então governo federal auxiliaram no acirramento às crises: institucional, política e econômica. Problemas estes totalmente incompreendidos por grande parcela do povo brasileiro, que ao invés de lutarem pela convocação de referendos e plebiscitos, por exemplo, veem como única ou melhor opção a volta da Ditadura Militar. Analfabetismo político ou jurídico?”José Alves Capanema Júnior (Jusnavegandi, 2016).
\end{abstract}

No Brasil do século XXI vigora elevada corrupção, malversação dos bens comuns, crimes diversos cometidos por servidores públicos, notadamente autoridades - principalmente as eleitas pelo voto do povo. Os mandatários nacionais, dos municípios mais longínquos à Brasília, abjuram os compromissos firmados, em tese de modo real, concreto e verdadeiro, em suas campanhas e naturalmente se deixam levar pela comodidade de desviar milhões, e até bilhões, de recursos públicos, que, ululantemente, fazem falta na saúde, na educação, no saneamento básico, entre outras prioridades populacionais, as quais, então, são escamoteadas pelo interesse privado egoístico. 
Em literalidade descritiva da realidade brasileira: grassam falcatruas e impunidade nesta nação! Consequência aceitável e óbvia é a inconformação do povo em relação à manutenção da existência do atual sistema político, seja na forma de eleições (com complicados financiamentos de campanhas possibilitadores de corrupção, emprego de propinas etc.), seja no vigor e exagero de algumas legislações esquizofrênicas beneficiadoras apenas das elites, do agronegócio, da indústria. Está clarividente que após três décadas da (re)democratização institucional do país, o complexo sistema político-jurídico implementado pela Constituição Federal de 1988 encontra-se fatigado pela demagogia e pelo engodo dos canalhas regentes do coral público brasileiro.

Portanto, ad effectum desta situação conturbada por que passa o Brasil, é compreensível a indignação de seu povo quanto à legitimidade dos poderes instituídos e suas ações. A revolta é consequência perene de qualquer senso de injustiça. De revés, porém, vale perguntarmos: mesmo em meio à incapacidade dos políticos civis de bem gerirem o país, é aceitável que parte do povo peça, em algumas manifestações, a volta dos militares ao poder? Seria possível e apropriada uma intervenção militar com o desejo de "limpar" a corrupção do Brasil e "purificar" a nascitura democracia da Terrae Brasilis? Por que seriam os militares seres diferenciados para uma missão como esta? Pensar, sócio-juridicamente, sobre tais questões é nosso escopo neste escrito.

Comecemos, pois, com uma reflexão signológico-imagética, cotejando as duas imagens seguintes. Façamos leituras mentais sobre seus significados, para cada um de nós - posto que somos únicos e teremos leituras sempre irrepetíveis.

Será que, mesmo a partir de nossos olhares particulares e incomparáveis, concordamos e dessumimos, em consensus omnium, ser muito contraproducente pedirmos a volta dos militares ao governo federal após tudo de ruim e desumano que eles fizeram no poder? Bem, prossigamos em nossa análise e, ao fim, teçamos nossas considerações sobre o "todo" das principais perspectivas e pontos de tensão existentes nesta questão social. 


\section{ACORDANDO A MEMÓRIA: QUEM ESTAMOS PEDINDO QUE VOLTE? O QUE FOI O REGIME MILITAR DE 1964-1985?}

Nos discursos de pessoas consternadas pela corrupção elevada e pela impunidade dos dilapidadores da res pública surgem signos como "os militares, apesar de tudo, são honestos e somente maltratam quem não é cidadão de bem" e "os militares fizeram o milagre econômico, época em que o Brasil mais cresceu", entre outros. Nesse sentido, para analisarmos os reclames pelo retorno dos militares ao controle do governo nacional, é relevante, primeiramente, que lembremos, ainda que perfunctoriamente, dos fatos que marcaram o último período em que os militares estiveram no poder: 1964-1985.

Isso, porquanto, grosso modo e em tese, os militares no poder sempre agirão como militares e, a partir disso, pedir militares no poder novamente nada mais é do que pedir o retorno do último regime militar vivido. Não é exagero, bem sabemos todos! Hoje temos tecnologias, globalização, a Guerra Fria não mais existe etc., mas é patente que militar, quando assume o poder, não aceita ordens de civis, mesmo que de autoridades investidas de poder político. Os próprios militares asseveram, nos bastidores, serem uma instituição independente que não deve obediência ao ministro da Defesa nem ao presidente da República, apenas "à Constituição".

Os militares possuem, psicologicamente, programações mentais para obedecerem somente aos seus princípios militares, ao Direito castrense e aos seus superiores hierárquicos dentro da militariedade. É utopia pensar na possibilidade de um modelo híbrido de "militares no poder mais democracia", bem como de um "governo militar" ad tempus apenas para "limpar o Brasil". Os militares são militares, militam sempre em suas causas, defendem suas perspectivas de classe, de organização, rigidez, comando e força.

Nesse rumo, passamos agora a rememorar, em síntese, o regime militar brasileiro do século passado. Este foi um período controverso. Muitos dizem que não houve torturas coisa alguma, outros que a ditadura brasileira foi a mais branda da "América latina" - como se fosse factível existir uma ditadura branda; outros propalam que este foi um regime sim muito cruel - cremos nisso. Alguns dizem, ainda, que foi o período em que o país mais se desenvolveu economicamente. Não temos como saber 
verdadeiramente, assim aqui abordamos apenas perspectivas bibliográficas.

Diz-nos a história inventada pelas letras de tantos, como Menezes (2006), que entre 1956 e 1961 o Brasil foi governado pelo presidente eleito Juscelino Kubistchek de Oliveira. Nesta época, não havia o instituto da reeleição. Em 1961, foi eleito à presidência da República Jânio da Silva Quadros. As eleições para presidente e Vice eram realizadas separadamente e para Vice-presidente foi eleito João Belquior Marques Goulart, conhecido como Jango, que já havia sido o Vice-presidente no governo de Juscelino Kubistchek.

Por razões que não se sabe exatamente até hoje, em 25 de agosto de 1961, apenas sete meses depois de tomar posse, Jânio Quadros renunciou à presidência da República. Segundo alguns, foram os militares que o pressionaram a sair e o motivo foi o fato de que Jânio aparentemente tinha tendências de comunista ${ }^{2}$, pois promoveu medidas estranhas, como a proibição de brigas de galo, do uso de biquínis em praias, além do que condecorou no Brasil com a Ordem do Cruzeiro do Sul o guerrilheiro cubano Che Guevara, um dos maiores inimigos dos Estados Unidos da América (EUA). Nessa direção, muitos expendem que a burguesia brasileira (a classe média e os ricos) e os militares, apoiados pelos EUA, começavam a se movimentar nos bastidores, temendo que no país fosse instaurado um governo comunista ${ }^{3}$ (MENEZES, 2006).

Essa tensão, diz Menezes (2006), se agravou pelo fato de que quando Jânio renunciou, seu Vice-presidente, Jango, estava em missão oficial na China, que vivia no auge de seu comunismo. Ficou firmado entre os militares e o Congresso Nacional que Jango poderia assumir, mas a Constituição foi modificada e passou a viger no país o parlamentarismo. Foi uma forma que os conservadores elitistas encontraram de limitar os poderes de Jango. O governo do país passou a ser de competência de um primeiro-ministro. O primeiro político eleito para o cargo foi Tancredo Neves.

\footnotetext{
${ }^{2}$ Naquela época, as pessoas viam os comunistas, de um modo geral, como seres radicais, guerrilheiros, pessoas que queriam pôr fim ao Estado e tornar todos os bens privados públicos. Por isso, criou-se uma ideologia forte sobre os intelectuais e militantes políticos que se declaravam comunistas.

${ }^{3}$ Cremos que de fato alguma coisa ou alguém deve ter pressionado Jânio a renunciar, pois não podemos pensar que ele mesmo passou a ter desinteresse pela política; se o fosse, não teria a ela retornado como prefeito eleito de São Paulo em 1986. Devemos sim conjecturar que algo forçou Jânio a renunciar, afinal não é todo dia que se abandona a presidência da República. Ele mesmo disse na sua carta de renúncia: "Forças terríveis se levantaram contra mim [...]".
} 
Em 1963, Jango, com o desejo de voltar a ter seus poderes, organizou um plebiscito, por meio do qual o povo votou pela volta do presidencialismo. Jango voltou a governar e impôs algumas medidas que aparentemente, dizem alguns, não agradaram as elites agrárias e industriais da nação. Implementou as chamadas "Reformas de Base" e o "Plano Trienal". Algumas metas constantes nestes programas esbarraram em privilégios seculares. Jango deu ênfase à reforma agrária, cortou investimentos em empresas estatais, estatizou outras privadas e elevou impostos incidentes sobre agrupamentos sociais de rendas altas. As tais Reformas de Base iam de encontro aos anseios das elites ${ }^{4}$ de forma acentuada. Jango prosseguia em suas metas, pois contava com o apoio dos servidores públicos, dos universitários, das massas trabalhadoras e das associações de classe (MENEZES, 2006).

No entanto, os embates práticos eram inescapáveis. Houve vários confrontos entre latifundiários e camponeses. Jango, com seu radicalismo político, contrapôs-se diretamente ao grande capital. No dia 19 de março de 1964, setores da direita, pessoas de classe média, da burguesia e da ala conservadora da Igreja Católica, apoiados por militares, reuniram cerca de meio milhão de pessoas no Rio de Janeiro numa manifestação chamada "Marcha pela família, com Deus e pela liberdade", onde o principal pedido era a saída da Jango (MENEZES, 2006).

O presidente Jango apoiou e anistiou de qualquer penalidade militares do baixo escalão da Marinha que estavam realizando uma espécie de greve. Os militares do alto escalão da República não gostaram. Começava ali uma conspiração, dizem. Em 31 de março de 1964, o General Olímpio Mourão Filho movimentou tropas de Juiz de Fora para o Rio de Janeiro. Jango, sabendo que os militares o queriam tirar da presidência, temendo por sua segurança, viajou para Porto Alegre, ficou alojado na casa do General Machado Lopes, comandante do Exército daquela região. Lá conversou com Leonel Brizola, que o incentivou a ir para a batalha contra os militares. Jango não quis, preferiu evitar um derramamento de sangue e pediu asilo político ao Uruguai $^{5}$ (MENEZES, 2006).

\footnotetext{
${ }^{4}$ Somos dos que pensam que a maioria dos entraves políticos pátrios sempre esteve ligada a questões econômicas, onde os que têm não querem deixar de ter e para tal impedem os que não têm de terem.

${ }^{5}$ Vindo a falecer depois em 1976 na Argentina de um suposto infarto - alguns dizem que ele foi envenenado a mando dos militares que governavam o Brasil. Por oportuno, cabe ressaltarmos que em 18 de dezembro de 2013 o Congresso Nacional, reunido em sessão simbólica, por conta de várias investigações da Comissão Nacional da Verdade, a comissão do governo federal responsável por
} 
Na madrugada de $1^{\circ}$ de abril de 1964 os militares tomaram o poder - outros dizem que foi ainda em 31 de março (MENEZES, 2006). O Congresso Nacional declarou vago o cargo de presidente e deu posse ao presidente da Câmara, o Deputado Raineri Mazzilli, o qual efetivamente não detinha poder algum, pois o país passou a ser governado por uma junta, autodenominada "Comando Supremo da Revolução" ${ }^{6}$, composta pelos militares General Artur da Costa e Silva, Almirante Augusto Rademaker Grunewald e Brigadeiro Francisco de Assis Correia de Melo, os quais geriram a nação entre $1^{\circ}$ e 15 de abril, quando entregaram o poder ao presidente eleito indiretamente pelos militares, o Marechal Humberto de Alencar Castelo Branco, que governou até 1967.

Após, lembra Menezes (2006), se sucederam no governo os Generais Artur da Costa e Silva, entre 1967 e 1969, Emílio Garrastazu Médici, entre 1969 e 1974, Ernesto Geisel, entre 1974 e 1979, e João Batista Figueiredo, entre 1979 e 1985. Pelo exíguo espaço e superficial profundidade analítica desta seção do texto, aqui não nos quedaremos a tecer comentários extensos sobre este período histórico. O essencial é lembrarmos que o "governo militar" de 1964-1985 foi um período confuso da política pátria. Objetivava apenas cessar um complexo de crises que mateavam o Brasil, mas foi ficando, ficando. Os militares foram gostando do poder. Foram torturando e perseguindo opositores. Manipulando o Congresso Nacional. Governando por meio de decretos autoritários (Atos Institucionais). Cerceando liberdades.

Naquele período, a bruteza dos militares se deveu ao fato de que:

O grupo militar que tomou o poder em 1964 vinha de uma tradição militar mais antiga, que remontava à participação do Brasil na II Guerra. A participação do Brasil ao lado dos países aliados acabou sedimentando uma estreita vinculação entre os oficiais norteamericanos e militares brasileiros, como os generais Humberto de Castelo Branco e Golbery Couto e Silva. Terminada a guerra, toda uma geração de militares brasileiros passou a frequentar cursos militares norte-americanos. Quando esses oficiais retornavam dos

\footnotetext{
investigar os atos ocorridos durante o governo militar, devolveu simbolicamente o mandato presidencial de João Goulart. O relatório final dessa comissão pode ser acessado em: <http://www.cnv.gov.br/>; Acesso em: 10 fev. 2018.

${ }^{6}$ Os militares viam aquele golpe na democracia como uma Revolução contra a tentativa de estabelecimento de um governo comunista, que na visão deles tentava ser implementado no país por Jango e seria ruim - para eles.
} 
EUA, já estavam profundamente influenciados por uma concepção de 'defesa nacional' (PRIORI et al., 2012, p. 199-200).

Paradoxalmente, os militares implementaram algumas políticas econômicas de sucesso momentâneo, levaram a efeito várias obras importantes para o país, trouxeram investimentos estrangeiros. Contudo, obviamente - pela prudência do respeito aos direitos humanos, na balança histórica pesam os aspectos negativos dos governos militares. Os militares exageraram na força contra o povo que exigia a volta da democracia e das liberdades sociais inerentes aos seres humanos. Melhor: erradamente foram com força física contra o povo, pois nenhuma força contra o povo pode ser permitida!

Está mais do que confirmado em nossa época, após vários estudos, pesquisas, filmes, documentários e narrativas críveis de pessoas ainda vivas, que os militares torturaram, exilaram e mataram milhares de pessoas naquele período. De lá até aqui, "constatou-se que a existência de uma administração democrática foi fictícia, haja vista o papel repressor desempenhado pelos órgãos policiais a fim de suplantar possíveis distúrbios sociais que afetassem o andamento das atividades do Executivo" (PRIORI et al., 2012, p. 202).

Decerto, quanto às nossas reminiscências do período do regime militar passado:

Essa história [...] precisa passar. Mas para isso precisa ser passada a limpo. E parte importante dessa limpeza incumbe às Forças Armadas brasileiras, por causa do problema dos desaparecidos. Elas continuam em débito com o dever ético de tornar públicos os arquivos e informações que detenham sobre o destino desses [...] mortos. Isso, sim, as reconciliaria de vez com a Nação (OLIVEIRA, 2011, p. 24).

Entretanto, nem por isso, devemos esquecê-la. É prudente não querermos jamais outros governos militares, na medida em que parece viger uma subsunção matemático-somativa no exercício de governos militares, qual seja: governo militar $=$ - liberdades + reação de parte do povo + violência/truculência. 
Mas, afinal, é ou não possível uma intervenção militar no atual Brasil democrático, com o objetivo de cessar/atenuar a terrífica onda corruptiva vigorante nas instituições públicas? Do ponto de vista prático, infelizmente, os militares - e quaisquer outras pessoas/forças com algum poder bélico, podem tomar o poder quando quiserem, basta agirem, saírem às ruas armados. Porém, no enfoque político-jurídico democrático existe tal factibilidade? Desde 2013, "ocorreram manifestações populares contra o governo brasileiro, onde os manifestantes pediam em cartazes intervenção militar constitucional como solução para resolver questões referentes à economia, corrupção e segurança nacional, e a deposição da presidente Dilma Rousseff' (FERREIRA, 2015, p. 1).

Alguns cidadãos têm pedido uma intervenção militar, porquanto:

Com o país submerso em um mar de lama, quando não há mais confiança nos poderes políticos constituídos e até o Judiciário parece mais político-ideológico que jurisdicional (leia-se um STF aparelhado), ao cidadão sobrou acreditar tão apenas nas instituições de controle (MP e PF) que parecem insistir na busca de um estado de salvação e limpeza do país, já que instituições pautadas na meritocracia dos concursos públicos onde a política e o aparelhamento se faz mais complexo e dificultoso [onde se enquadram as Forças Militares também]. A Operação Lava Jato nos mostrou um país absolutamente dominado por um complexo sistema de corrupção [...] que ganhou tentáculos por toda ambiência política, afetando inclusive as principais empresas do país. Em meio ao maior sentimento de descrédito interno e internacional é que parcela relevante da sociedade grita mais do que nunca por uma intervenção militar (SARMENTO, 2016, n.p.).

O que seria essa "intervenção militar constitucional"? Por certo, estão os que se manifestam neste sentido, os "intervencionistas", a se referir a alguma coisa presente em nossa atual Constituição, a Constituição Federal de 1988. Não falam os reivindicantes em "ditadura militar", em "exército nas ruas" do nada, abruptamente. Falam em uma "intervenção como manda a Constituição". Todavia, será que a Constituição manda mesmo isso? Poderíamos prima facie economizar vocábulos logo pensando: depois de 21 anos de uma ditadura militar, fizeram uma nova Constituição em 1988 e ainda colocaram nela a possibilidade dos militares intervirem quando quiserem? À evidência, não!

Para exemplificarmos os pedidos feitos por certa parcela do povo nacional, vale leitura de situação curiosa vivida pela pesquisadora jurídica Maíra Zapater (2015, n.p.): 
[Em 27 de junho de 2015] deparei-me [em SP] com um grupo equipado com carro de som, em que uns tantos trajavam calças camufladas e outros muitos desfilavam envoltos em bandeiras do Brasil. Além do lindo pendão da esperança e símbolo augusto da paz, ostentavam outra bandeira: a da intervenção das Forças Armadas no atual governo. Sim, ainda que um tanto minguada, é verdade (mas pelos pontos ali defendidos, em preocupante quantidade de adeptos, ainda que fosse o grupo composto por metade das cerca de cem pessoas que ali estavam), tratava-se de uma manifestação popular pedindo expressamente o que denominaram "intervenção constitucional". Nesse ínterim de rica experiência de exercitar a tolerância democrática à manifestação da opinião de outrem, um moço nascido pelo menos uns bons sete ou oito anos após a promulgação da Constituição Federal de 1988 (e usando as tais calças que em nada o camuflavam na selva de asfalto da Avenida Paulista) me entregou um panfleto com o logotipo da organização - uma elipse dividida por uma linha diagonal, metade verde, metade amarela, com a inscrição "Brasil acima de tudo UND - União Nacionalista Democrática", seguido de pequeno texto com o resumo das reivindicações do ato, aqui integralmente transcrito: "INTERVENÇÃO CONSTITUCIONAL JÁ! A NAÇÃO BRASILEIRA tem o PODER, o DIREITO e o DEVER de INTERVIR EM SUAS INSTITUIÇÕES, sempre que estiverem fragilizadas ou USURPADAS pelo CRIME, como ocorre. A Constituição Federal, que é a 'convenção do condomínio' BRASIL, em seus artigos 142 e 144, determina o dever da NAÇÃO intervir nas suas instituições, com os seus instrumentos de segurança e poder: as FORÇAS ARMADAS. É público, que o crime USURPOU os Poderes Constitucionais, para a prática sistemática de delitos. Portanto, cumpre a nós, NAÇÃO Brasileira, INTERVIR CONSTITUCIONALMENTE, utilizandonos das nossas FORÇAS ARMADAS ou, permaneceremos como escravos do CRIME ORGANIZADO! LIBERDADE AINDA QUE TARDIA!" Enquanto o manifestante da vez bradava a plenos pulmões no alto-falante que, textualmente, não estavam ali "por ideologia", que não eram "motivados por ideologia", mas sim "motivados pela defesa da pátria e da nação", li o tal papel e ri irônica (por dentro, pois tive receio que o grupo ao redor não estivesse lá muito interessado em exercitar sua própria tolerância a qualquer outra manifestação de opinião, ainda que simbolizada por um sorriso amarelo) e pensei com meus botões: "mas, gente, qual a edição da Constituição Federal que esse povo leu?" Afinal, o texto dos artigos constitucionais mencionados no panfleto que me fora entregue pelo menino é bem diferente da interpretação dada pelos manifestantes. (Grifos da autora)

Vê-se que, neste exemplo presenciado pela pesquisadora, os manifestantes citam os artigos 142 e 144 da Constituição Federal de 1988 para fundamentar seus pleitos. São esses dispositivos, ao lado dos artigos 34, 136 e 137, também da Constituição de 1988, exatamente os mais citados de nossa Carta Política pelos que advogam a favor de uma 
intervenção militar. A partir de agora, passamos a analisar tais dispositivos constitucionais.

Exala o artigo 142 da Constituição Federal de 1988:

Art. 142. As Forças Armadas, constituídas pela Marinha, pelo Exército e pela Aeronáutica, são instituições nacionais permanentes e regulares, organizadas com base na hierarquia e na disciplina, sob a autoridade suprema do Presidente da República, e destinam-se à defesa da Pátria, à garantia dos poderes constitucionais e, por iniciativa de qualquer destes, da lei e da ordem (BRASIL, 1988). (Grifos nossos)

Para Sarmento (2016), os defensores da intervenção militar alegam, esquizofrenicamente, que a defesa da Pátria, a garantia dos poderes constitucionais e a garantia da lei e da ordem são atribuições precípuas das Formas Militares pátrias e pronto, pouco importando se elas devem ser comandadas supremamente pelo presidente (civil) da República. Para o autor, os intervencionistas aproveitam-se, ainda, do abstracionismo do conceito de ordem (pública), "vez que a Constituição da República não define o que seja ordem pública (conceito jurídico indeterminado)" (SARMENTO, 2016, n.p.).

Segundo pesquisador, a Emenda Constitucional no 23/1999, que criou o Ministério da Defesa, manteve o status de ministro de Estado aos Comandantes das três armas (Exército, Marinha e Aeronáutica), pois foram mantidas integralmente as prerrogativas de foro para julgamento de crimes de responsabilidade e comuns dessas autoridades, o que culminou numa espécie de "esvaziamento dos poderes do Ministério da Defesa em relação às Forças Armadas, que, ideologicamente, julgam-se independentes, face à 'imaturidade' e 'indisciplina' dos civis" (SARMENTO, 2016, n.p.).

Este artigo 142 da Constituição é deveras bem complexo. Por sua redação, para os intervencionistas, não parece haver impedimento para que as Forças Militares tomem o poder, mesmo destituindo o presidente civil, pois o essencial é manter a ordem e a lei vigentes. Mas, o que seria a ordem? Qual o limite? E se os comandantes militares não destituírem o presidente e apenas se apresentarem a ele dizendo que vão o "ajudar" a pôr ordem nas coisas, por certo ele negaria a ajuda ao ver milhares de homens armados (?). Para onde isso caminharia hoje em dia?

Conforme os intervencionistas, o artigo 142 da Constituição é claro no sentido de que: 
Não poderiam os Militares entregar o poder aos civis [em 1985] sem um mecanismo de tutela em que pudessem reconquistar o poder, caso os civis falhassem novamente na manutenção da lei e da ordem. Sendo assim, os Militares permitem o desenvolvimento da Democracia, mas condicionada à conveniência de intervenção militar na Política, caso haja perigo à lei e à ordem. Assim, é perfeitamente possível a convivência [de] enclaves autoritários no Estado Democrático, pois aqueles permitem o governo democrático até quando convier às Forças Armadas. Não existiria, em evidência, um modelo de reverência dos militares ao poder civil. A autoridade suprema do Presidente da República sucumbe quando as Forças Armadas concluam que a lei e a ordem estão sendo ameaçadas pelo próprio Presidente da República. Na Constituição Federal de 1988, não existiriam mecanismos de controle do comportamento dos Militares nos tempos de crise (SARMENTO, 2016, n.p.). (Grifos nossos)

\section{Para Sarmento (2016, n.p.), todavia:}

[...], a manutenção do art. 142, da Constituição Federal, tal como está escrito, fragiliza, por demais, a democracia, vez que coloca em risco a ordem constitucional duramente conquistada ao longo da lenta, gradativa e segura distensão. Significa dizer que os Militares ficam fora do poder, pois não pretendem governar o país, função inerente aos políticos democraticamente eleitos. Os Militares reconhecem que não têm formação política e quando assumem o poder, a máquina estatal fica ao encargo de tecnocratas e burocratas. [Fica parecendo que] os Militares deferem o poder aos civis. Contundo, se os políticos e a sociedade civil demonstrarem imaturidade e indisciplina, pondo em risco a lei e a ordem pública, a intervenção militar sobreviria, suprimindo, momentaneamente, a democracia. Os Militares mantêm o "status" de observadores do processo político democrático, enquanto estabilizado. (Grifos do autor)

Outrossim, os intervencionistas também se valem do artigo 34 da Constituição Federal de 1988 para fundamentar seus pedidos. Vocifera tal dispositivo:

Art. 34. A União não intervirá nos Estados nem no Distrito

Federal, exceto para: I - manter a integridade nacional; II - repelir invasão estrangeira ou de uma unidade da Federação em outra; III - pôr termo a grave comprometimento da ordem pública; IV garantir o livre exercício de qualquer dos Poderes nas unidades da Federação; V - reorganizar as finanças da unidade da Federação que: a) suspender o pagamento da dívida fundada por mais de dois anos consecutivos, salvo motivo de força maior; b) deixar de entregar aos Municípios receitas tributárias fixadas nesta Constituição, dentro dos prazos estabelecidos em lei; VI - prover a execução de lei federal, ordem ou decisão judicial; VII - assegurar 
a observância dos seguintes princípios constitucionais: a) forma republicana, sistema representativo e regime democrático; b) direitos da pessoa humana; c) autonomia municipal; d) prestação de contas da administração pública, direta e indireta. e) aplicação do mínimo exigido da receita resultante de impostos estaduais, compreendida a proveniente de transferências, na manutenção e desenvolvimento do ensino e nas ações e serviços públicos de saúde (BRASIL, 1988). (Grifos nossos)

Sobre essa intervenção da União nos Estados (ou destes em seus municípios, conforme artigo 35 da Constituição), fala-se de um caráter notadamente econômico, pois:

\begin{abstract}
A Intervenção Federal, prevista no artigo 34 da Constituição, é o ato político que consiste na incursão da entidade interventora nos negócios da entidade que a suporta. O estado federal baseiase no princípio da autonomia de suas entidades componentes. Os estados-membros não são soberanos, por isso não podem contrariar os ditames da soberania nacional, que é una, indivisível e pertence à União. $\mathrm{O}$ equilíbrio federativo é realizado por meio do instituto da Intervenção Federal, único instrumento eficiente e objetivo para garantir as características políticas dessa forma de estado. Assim, a Intervenção se constitui em medida excepcional, ocorrendo em situações críticas que põem em risco a segurança do Estado, o equilíbrio federativo, as finanças estaduais e a estabilidade da ordem constitucional (SILVA, 2006, n.p.).
\end{abstract}

Do exposto, não se verifica existir qualquer possibilidade de a União intervir, por meio das Forças Armadas, em todos os Estados da federação em um só momento, a fim de criar uma espécie de "intervenção nacional". A intervenção da União em entes federativos é taxativa, passível de ocorrer apenas em algumas situações excepcionais, onde se verifique verdadeiro caos social e administrativo, bem como possui vários requisitos institucionais e democráticos, como dimana o artigo 36 da Constituição. Os intervencionistas enaltecem também o artigo 144 da Constituição Federal de 1988, mas este apenas narra ser função das polícias militares a preservação da segurança, da ordem e do patrimônio públicos, nada de extraordinário.

Ademais, quanto aos artigos 136 e 137 da Constituição, referentes ao Estado de Defesa e ao Estado de Sítio, verifica-se também não se poder cogitar nenhuma possibilidade legal de intervenção militar, pois sempre, no seio destes institutos, o presidente da República comandará as Forças Armadas. Vale lembrar: 
O Estado de Defesa [...] é uma situação em que se organizam medidas destinadas a debelar ameaças à ordem pública ou à paz social. Em outras palavras, em função do disposto no artigo $136 \mathrm{da}$ Constituição, essa medida consiste na instauração de uma legalidade extraordinária, por certo tempo, em locais restritos e determinados, mediante decreto do Presidente da República, ouvidos o Conselho da República e o Conselho de Defesa Nacional, órgãos consultivos do Presidente, com a finalidade de preservar a ordem pública ou a paz social ameaçadas por grave e iminente instabilidade institucional ou atingida por calamidades de grandes proporções na natureza. O Estado de Sítio, conforme o artigo 137 da Constituição, consiste na instauração de uma situação extraordinária, por determinado tempo e em certa área, objetivando preservar ou restaurar a normalidade constitucional, perturbada por motivo de comoção grave de repercussão nacional, ineficácia das medidas durante o Estado de Defesa ou por situação de beligerância com Estados estrangeiros. O Estado de Sítio é decretado pelo Presidente da República, após ter ouvido os Conselhos da República e de Defesa e ter sido autorizado pelo Congresso Nacional. Esse decreto instaura uma normatividade especial com a indicação do prazo de vigência, das normas necessárias à sua execução e das garantias constitucionais suspensas. O juízo de conveniência da decretação do Estado de Defesa ou do Estado de Sítio cabe ao Presidente da República, observando as normas constitucionais. Os controles político e jurisdicional dessas medidas serão realizados pelo Congresso Nacional e pelo Poder Judiciário respectivamente. Os executores ou agentes que cometerem abusos, ilícitos ou excessos ficarão sujeitos a processo judicial, durante ou após o período emergencial (SILVA, 2006, n.p.).

\section{Assim, quanto aos mencionados dispositivos da Carta Política vigente devemos concluir que:}

A Constituição brasileira de 1988 não autoriza nenhuma forma de intervenção militar para mudança de governo. As únicas formas constitucionais de intervenção são as regidas por seus artigos 34 (intervenção da União em Estado ou no Distrito Federal) e 35 (intervenção de Estado em Município). Absolutamente inconstitucional revelar-se-ia uma intervenção militar com o fito de assumir o poder e destituir a ordem democrática, uma garantia constitucional da sociedade, como se depreende de todo o estatuído pela Constituição, e em especial ao se vociferar pelo Estado Democrático de Direito logo em seu artigo $1^{\circ}$ localizado no Título V (Da Defesa do Estado e Das Instituições Democráticas). Vivemos em uma democracia representativa, qualquer ação militar prescinde ser requisitada por um dos três "poderes constitucionais", nos termos do princípio da Separação dos Poderes. Não se admite que o pedido das ruas, ainda que pela maioria do povo (o que não se revela uma verdade hodierna) tenha o condão de encontrar o respaldo da Lei Maior do país para facultar às Forças Armadas 
derrubar o Presidente. A Presidência da República, vale dizer, é indicada pela Constituição como a "autoridade suprema" sob a qual as Forças Armadas se organizam. Isso é literal, expresso. Revelarse-ia indelével quebra de hierarquia uma intervenção dos militares para destituição de sua liderança suprema, nos termos do art. 142 (SARMENTO, 2016, n.p.).

Por fïm, resta claro que "não é possível a intervenção militar acontecer no país sem ferir o Estado Democrático de Direito" (FERREIRA, 2015, p. 1). Qualquer discurso "defendido para justificar o fenômeno da ditadura constitucional cria uma situação de risco extremo à democracia e ao Estado de Direito" (FERREIRA, 2015, p. 3). Toda ação militar realizada no país, em caráter nacional, com o véu de "governo provisório", quando não realizada nos moldes da Constituição Federal de 1988, será um golpe de Estado, um governo ditatorial, um regime ilegítimo. Noutras palavras, toda intervenção militar no Brasil será procedimento "antidemocrático se não acontecer senão pelas vias dos artigos 34 e 142" (FERREIRA, 2015, p. 7) da Constituição Federal de 1988, sempre sob o comando do presidente (civil) da República, devidamente eleito, nem que seja como Vicepresidente, inicialmente.

\section{4 O DECRETO № 3.897, DE 24 DE AGOSTO 2001: USO
DAS FORÇAS MILITARES PELA PRESIDÊNCIA DA
REPÚBLICA PARA MANUTENÇÃO DA LEI E DA
ORDEM}

Fora os dispositivos constitucionais mencionados, no seio do tema ora debatido, surge como também interessante a normatividade do Decreto n. ${ }^{\circ} 3.897$, de 24 de agosto de 2001, assinado pelo então presidente Fernando Henrique Cardoso. Tal norma, conforme sua ementa, "fixa as diretrizes para o emprego das Forças Armadas na garantia da lei e da ordem". Segundo o Decreto, em seu artigo 2. ${ }^{\circ}$, nos termos dos artigos 142 e 144 da Constituição Federal de 1988, da Lei Complementar 97/1999, do Decreto 88.777/1983 e do Parecer AGU nº GM-025, de 10 de agosto de 2001, "é de competência exclusiva do Presidente da República a decisão de emprego das Forças Armadas na garantia da lei e da ordem".

Esta norma, longe de permitir intervenções militares no país de modo nacional, é apenas uma normatização sobre como deve ocorrer a 
intervenção da União (governo federal) no Distrito Federal ou em algum Estado, ou de algum Estado em um de seus municípios, quando tiver sido quebrada a ordem e/ou a lei. "A decisão presidencial poderá ocorrer por sua própria iniciativa, ou dos outros poderes constitucionais, representados pelo Presidente do Supremo Tribunal Federal, pelo Presidente do Senado Federal ou pelo Presidente da Câmara dos Deputados" (art. 2. ${ }^{\circ}, \S 1^{\circ}{ }^{\circ}$ ). "O Presidente da República, à vista de solicitação de Governador de Estado ou do Distrito Federal, poderá, por iniciativa própria, determinar o emprego das Forças Armadas para a garantia da lei e da ordem" (art. 2. $\left..^{\circ} \S 2 .^{\circ}\right) \mathrm{em}$ situações focais e temporárias.

Tais intervenções somente serão possíveis quando as polícias militares não derem conta de manter a ordem e o cumprimento da lei nos respectivos Estados brasileiros. Conforme o artigo 3. ${ }^{\circ}$ do Decreto:

\begin{abstract}
Na hipótese de emprego das Forças Armadas para a garantia da lei e da ordem, objetivando a preservação da ordem pública e da incolumidade das pessoas e do patrimônio, porque esgotados os instrumentos a isso previstos no art. 144 da Constituição, lhes incumbirá [às Forças Militares], sempre que se faça necessário, desenvolver as ações de polícia ostensiva, como as demais, de natureza preventiva ou repressiva, que se incluem na competência, constitucional e legal das Polícias Militares, observados os termos e limites impostos, a estas últimas, pelo ordenamento jurídico (BRASIL, 2001).
\end{abstract}

Nesse sentido, sabendo-se da gravidade do emprego das Forças Armadas, dada à força bélica dos militares pátrios, consoante o artigo $5 .^{\circ}$ do Decreto:

O emprego das Forças Armadas na garantia da lei e da ordem,
que deverá ser episódico, em área previamente definida e ter a
menor duração possível, abrange, ademais da hipótese objeto dos
arts. 3o e 4-, outras em que se presuma ser possível a perturbação
da ordem, tais como as relativas a eventos oficiais ou públicos,
particularmente os que contem com a participação de Chefe de
Estado, ou de Governo, estrangeiro, e à realização de pleitos
eleitorais, nesse caso quando solicitado (BRASIL, 2001). (Grifos
nossos)

Por fim, mediante o artigo $7 .^{\circ}$ do Decreto, quando requisitadas pelo presidente da República para a manutenção da ordem, as Forças Militares deverão ser empregadas pelo ministro da Defesa, cabendo ao Gabinete de Segurança Institucional da Presidência da República o 
planejamento e controle das ações em todas as suas perspectivas e implicações.

Observa-se, assim, ser este Decreto mero normatizador das situações em que o convívio social em alguma localidade do país torne-se insustentável e seja necessário o uso dos militares federais. Podemos falar aí de uma invasão por alguma fronteira, de uma enorme rebelião em certo presídio, de elevado número de crimes, assaltos e/roubos levando caos total a alguma comunidade etc. Nada, porém, relativo a um governo militar provisório em caráter nacional, pois sempre as Forças Militares deverão obedecer ao presidente da República.

\section{5

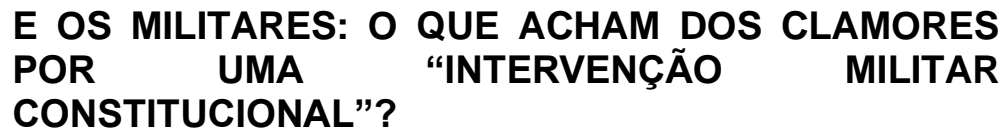

Em reflexo do comportamento da sociedade brasileira como um todo, dentro das Forças Armadas há militares que concordam com e defendem uma intervenção militar e há militares que riem desse tipo de pedido realizado por alguns cidadãos, o relevando, de forma acertada, como totalmente descabido, fora de questão e ilegal. Sem tocar profundamente no tema "ditadura de 64-85", estes últimos militares apenas aduzem que hoje em dia "os tempos são outros".

Capanema Júnior (2016), em artigo sobre a possibilidade jurídica ou não de uma intervenção militar, diz que o General Paulo Chagas, por exemplo, é uma das vozes em defesa da volta dos militares ao poder. Segundo o pesquisador, disse certa vez o General sobre uma intervenção militar nos rumos da política nacional: "[...] tábua da salvação para a Pátria ameaçada [...]". Já o General Eduardo Villas Bôas comandante do Exército brasileiro, segundo Capanema Júnior, em entrevista à Radio Itatiaia, classifica como "[...] tresloucados ou malucos [...]" aqueles que pugnam pelo retorno dos militares ao comando do país. Conforme o pesquisador, o referido comandante "demonstra ainda mais lucidez e compreensão do ambiente jurídico vigente, ao declarar que a atual Constituição Federal é absolutamente clara ao rezar que as Forças Armadas se subordinam ao presidente da República" (CAPANEMA JÚNIOR, 2016, n.p.). 
De fato, o General Eduardo Villas Bôas, Comandante do Exército, sempre teve um posicionamento republicano. Consoante o Site de notícias Brasil 247, o General disse em 2016:

\begin{abstract}
Eu acho lamentável que, num país democrático como o Brasil, as pessoas só encontrem nas Forças Armadas uma possibilidade de solução da crise, mas isto não é extensivo nem generalizado e, felizmente, está diminuindo bastante a demanda por intervenção militar [...]. Não há paralelo com 1964, primeiro porque hoje nós não temos o fator ideológico. Naquela época, nós vivíamos a situação de Guerra Fria e a sociedade brasileira cometeu o erro de permitir que a linha de fratura da Guerra Fria [a] dividisse. Isso não existe mais. O segundo aspecto é que hoje o Brasil tem instituições sólidas e amadurecidas, com capacidade de encontrar os caminhos para a saída dessa crise (BRASIL 247, 2016).
\end{abstract}

Segundo Capanema Júnior, outro nome de poder dentro das Forças Armadas que rechaça qualquer possibilidade de intervenções militares no governo federal é o General Gilberto Pimentel. Diz o pesquisador que este militar, em nome do Clube Militar (a principal associação dos militares brasileiros), certa vez disse: "[...] Garanto que isso [intervenção] não tem nada a ver conosco. Os militares não pensam nisso. Temos uma posição legalista. [...]. Queremos que o Brasil caminhe sempre dentro do constitucional [...]. O País não merece viver essa confusão".

Em sentido contrário, o General Antônio Hamilton Mourão, em setembro de 2017 passado, no auge de várias polêmicas denúncias de corrupção, inclusive no escalão primário de poder da presidência da República do governo Temer, se manifestou de forma enfática favoravelmente a uma intervenção militar. Segundo Mourão, ao ser perguntado sobre o tema, o Exército, naquele momento, não se movimentava diretamente para intervir, mas suas ações poderiam se dar na forma de "[...] aproximações sucessivas, até chegar o momento que ou as instituições solucionam o problema político, pela ação do Judiciário, retirando da vida pública esses elementos envolvidos em todos os ilícitos, ou então nós [Militares] teremos de impor isso".

As declarações do Militar foram polêmicas, ditas em um ambiente público - uma palestra, quando ele estava fardado, e vários setores da sociedade, inclusive o Ministro de Estado da Defesa, requereram ao Comando do Exército que punisse o Gen. Mourão. O Comandante do Exército afirmou que a questão foi resolvida internamente. 


\section{6 \\ E O PODER JUDICIÁRIO: O QUE PENSA SOBRE O TEMA?}

Como vimos, cabe tanto ao presidente da República quanto aos presidentes do Congresso Nacional e do Poder Judiciário (o/a presidente do Supremo Tribunal Federal) a convocação das Forças Armadas, sempre geridas pelo presidente da República, para fins de controle/manutenção da ordem e da lei. Nessa direção, como o Judiciário tem agido (politicamente) a querer a todo o custo processar e prender vários políticos envolvidos nos principais escanda-los descobertos recentemente, alguns intervencionistas também cogitam ser uma pretensão velada deste Poder a convocação das Forças Militares para que ele próprio, o Judiciário, possa governar a nação.

Tal pensamento, ululantemente, também está fora de questão e aplicabilidade. Em nosso tempo, a visão do Supremo Tribunal Federal sobre a atuação das Forças Armadas se esmera em defesa total dos direitos humanos fundamentais, notadamente as liberdades democráticas, o respeito ao voto e à legitimidade dos eleitos, principalmente do presidente da República, o qual somente pode ser afastado do cargo pelo Congresso Nacional.

Disse o ministro do Supremo Tribunal Federal Celso de Melo, por exemplo, no Habeas Corpus número 98.237, j. 15-12-2009, $2^{\text {a }}$ T, DJE de 6-8-2010, ser inadmissível que o Estado Brasileiro possa, como ocorreu na ditadura militar de 1964-1985, realizar perseguições a quem pensa diferente da cúpula do governo federal, pois:

\footnotetext{
[...] O Estado não tem o direito de exercer, sem base jurídica idônea e suporte fático adequado, o poder persecutório de que se acha investido, pois lhe é vedado, ética e juridicamente, agir de modo arbitrário, seja fazendo instaurar investigações policiais infundadas, seja promovendo acusações formais temerárias, notadamente naqueles casos em que os fatos subjacentes à persecutio criminis revelam-se destituídos de tipicidade penal. (BRASIL, STF, 2010).
}

Por certo, os cidadãos leigos (ou não) que defendem o fim da democracia o fazem por total desconhecimento da causa e falta de oportunidade de intervirem diretamente (mediante plebiscito, referendos, apresentação de anteprojetos de lei etc.) nos rumos da política nacional. Uma volta das Forças Armadas ao poder traria como consequente inelutável o fim do próprio direito de se manifestar pacificamente, dentre 
tantas outras liberdades, principalmente a de opinião, atingindo inclusive a liberdade de expressão de quem defende a ignomínia de uma "intervenção militar" e o Judiciário tem noção disso.

Os próprios militares, em sua maioria, como carreia o Coronel do Exército Silva (2006), em artigo sobre aspectos legais do emprego do exército na garantia da lei e da ordem, são defensores apenas das possibilidades de uso dos militares vigentes nos termos da lei e da Constituição Federal de 1988. "Em situações de maior gravidade [...] o presidente da República, através de decreto, regula a execução da Intervenção Federal, do Estado de Defesa ou do Estado de Sítio." (SILVA, 2006, n.p.). Jamais as Forças Armadas podem atuar sem a determinação do presidente da República e o Judiciário sabe disso.

Precisa ficar claro em nossas mentes que:

O emprego do Exército na garantia da lei e da ordem está
condicionado às situações de normalidade [vigência de leis] e
durante a vigência de intervenção federal, estado de defesa ou
estado de sítio, ao esgotamento da capacidade operativa das forças
de segurança estaduais e à convocação pelos representantes de
quaisquer dos Poderes da República. [...]. No âmbito interno, a
intervenção do Exército deve primar pelo respeito à legislação
vigente e, principalmente, às pessoas (SILVA, 2006, n.p.).
(Grifos nossos)

Fora isso, nas ações diárias de defesa da pátria e da ordem legal, cabe às Formas Militares atuarem nas fronteiras contra ilícitos transnacionais, em especial o narcotráfico e o contrabando de armas, bem como, quando requisitadas, na garantia da realização de eleições, quando as forças estatuais não possuem capacidade de fornecer à população a tranquilidade para exercer o seu direito do voto. E o Judiciário sabe disso!

\section{COMPORTAMENTO CIDADÃO-DEMOCRÁTICO MAIS APROPRIADO À QUESTÃO: LUGAR DE MILITAR É NO QUARTEL E NA POLÍTICA APENAS CIDADÃOS DEVIDAMENTE ELEITOS PELA MAIORIA!}

Qualquer governo militar, por não possuir as vestes da legitimidade nascitura do pleno exercício do voto livre, direto e secreto, tende a agir na plenitude do caráter organizacional e institucional de seus 
membros - os militares, ou seja: com força armada, ferocidade, intensidade física! Entretanto, isso tem explicações. Os militares são treinados/preparados para agirem com força, atuarem em guerras, vencerem inimigos, explodirem locais, matarem, morrerem etc. Possuem armamento pesado, praticam exercícios "brutos", intensos e exaustivos. São obedecedores de hierarquias internas de elevada seriedade, as quais, quando descumpridas, cominam sanções diversas - são acostumados a serem punidos (até com prisão interna) quando erram e, por isso, erram pouco e enojam o erro.

Por lógica, os militares quedam-se silentes em seus postos, aquartelados e quietos a exercer suas funções, as quais em elevada monta se resumem a treinamentos para quando se precisar deles. Não são servidores públicos comuns. São pessoas integrantes de forças especiais, o braço armado do Estado. Treinam, treinam e treinam para que o Estado tenha sua reserva de força preparada para disputas bélicas ou reações a invasões. Pelas querelas geopolíticas eliciadas com o surgimento da complexa globalização, a maioria das nações montou suas forças militares e investiu em armamentos bélicos, nucleares e químicos. Ter forças militares é normal e necessário!

Nesse intento, as Forças Militares não são preparadas para governarem politicamente um país. Malgrado os militares de elevada patente, como Generais, Almirantes, Brigadeiros e Marechais, durante suas carreiras, passem por várias e elevadas formações, com vários cursos nas áreas de Administração Pública Estratégica, Economia Internacional, Direito, Línguas Estrangeiras entre outras, bem como possuam elevado senso de civismo e patriotismo, a evolução humana nos mostra que o melhor caminho para a formação de governos de países é o pleno implemento da democracia.

Nesta, qualquer cidadão, do gari ao doutor em relações internacionais, pode ser candidato à presidência da República e a dinâmica do desenvolvimento nacional se dá nas lutas diárias entre as classes, sendo permitidos o debate e as discussões imanentes à democracia republicana. Assim, o comportamento cidadão-democrático mais apropriado é pensar: lugar de militar é no quartel e na política apenas cidadãos devidamente eleitos pela maioria! 


\section{CONSIDERAÇÕES FINAIS}

Ad summam, a alforria do Brasil de sua má gestão por políticos egoístas e interessados somente em dinheiro tem a ver com a educação. A resolução/amenização dos precípuos problemas brasileiros será sempre a longo prazo, pois este é um país de recente formação urbana, ainda fugitivo do patrimonialismo, do patriarcado, do coronelismo, do voto de cabresto, do populismo entre outras aberrações. A etiologia do roubar está ligada ao caráter da personalidade humana e este é aperfeiçoado na escola.

A tábua axiológica da vida humana é fomentada por boa e estruturada criação familiar-doméstica concomitante a uma educação social efetiva, direcionada a incutir valores, princípios e noções básicas de filosofia, história, sociologia, direito e psicologia nos aprendentes em geral. É somente imerso na sociedade dialógica em que vivemos, entendendo suas ideologias diversas, que construiremos/ratificaremos nossa bona fide, agindo sempre em prol de todos nós, de nosso bem comum.

Cremos que os homens públicos, notadamente os que lidam com o Direito - as leis, o principal instrumento responsável pelo fomento de políticas públicas e pela aplicação de recursos em benefício do povo aqueles homens engravatados "doutores sem doutorado" que amam falar uma língua que o povo não entende, pois fica fácil fazer tudo ao seu modo, ao modo da "mais prudente interpretação sistemática super hiper mega positivista amante do capital" - devem mudar.

Em nosso momento, precisamos buscar fortalecer nossas instituições fiscalizadoras do próprio Estado. Precisamos lutar por uma eficiente reforma política, pelo implemento de um sistema de aprovação da continuidade do andamento de mandatos presidenciais. Como enaltece Sarmento (2016, n.p.):

Em verdade precisamos de instrumentos democráticos como é o "Recall político/eleitoral" como forma de aprimoramento de nossa democracia. $\mathrm{O}$ instrumento de impeachment retira do povo e entrega aos seus representantes a possibilidade de "caçar" a representação, o mandato político, abrindo-se a oportunidade de conluios, tráficos de influências e troca de favores pelo poder, cada vez mais promíscuo e sem balizas morais. [...]. Devemos assim lutar para que a ordem democrática reste restabelecida não pelo deletério retorno de uma ditadura militar no contexto de uma "ordem impositiva moralizante" decepadora de parcela democrática fundamental, o que se revelaria ledo engano perceptivo, mas sim para que a democracia desviada que se pratica 
hoje não prospere ao ponto de com os mesmos atores político tornarem-se uma ditadura civil maquiada por uma Constituição relida pela elite detentora do poder, reinterpretada nos interesses desviados, como se faz com as leis Muçulmanas através do terror imposto por seus extremistas. (Grifos nossos)

Na democracia, na liberdade de pensamento, sempre haverá alguém que acreditará estar no emprego do exército do Estado a solução para todos os problemas. "Não é de hoje que são ouvidas insistentes vozes que bradam além das redes sociais, que saem às ruas conclamando por uma intervenção militar como medida 'única' com capacidade de moralização frente ao caos e desordem instalados" (SARMENTO, 2016, n.p.). Mesmo os que pedem os militares no poder somente o fazem porque na liberdade de pensamento podemos pedir o quisermos. Nesse diapasão, deviam tais pedintes lembrar-se que em "governo militares", por conveniência, a liberdade de pensamento é obliterada naturalmente, com o passar do tempo.

Devemos crer que a única forma viável de existir um governo federal com tom de gestão militar seria:

[...] pela criação de um partido militar (o que já está em andamento), que democraticamente restasse eleito pelo povo, e assim constitucionalmente legitimado no poder. [...] sendo esta a forma democrático-constitucional que os militares teriam para tentar o restabelecimento da ordem ascendendo ao poder sem que se aventasse da dação de um novo golpe militar (SARMENTO, 2016, n.p.).

No atual Brasil democrático, as Forças Armadas são apenas instituições responsáveis pela defesa da nação e manutenção da ordem e da lei, quando elas faltem, sempre sob o comando das autoridades civis instituídas (artigos 142 e 144 da Constituição Federal de 1988). São permitidas somente as decretações do Estado de Defesa e do Estado de Sítio e intervenções da União no Distrito Federal ou em Estados e destes em seus municípios para manutenção da ordem pública (artigos 34 e 35 da Constituição Federal de 1988), mas tudo sob o comando supremo do presidente da República, o qual poderá empregar as Forças Armadas nos moldes do Decreto n. ${ }^{\circ} 3.897 / 2001$.

Qualquer coisa diversa disto será um golpe de Estado, cabendo apenas ao Congresso Nacional afastar e julgar o presidente da República em crimes de responsabilidade, e ao Supremo Tribunal Federal, em relação 
a crimes comuns. Nossas insatisfações com presidentes da República civis e outras autoridades políticas corruptas e imorais têm como solução o poder de nosso voto e de nossas manifestações.

Evidentemente:

Uma intervenção militar com o fito da derrubada do poder constituído revelar-se-ia novo golpe militar, ainda que se fizesse de forma temporária para o restabelecimento da ordem pelos motivos arrolados [pelos intervencionistas]. A intervenção militar não está entre as formas de destituição do poder admitidas pela Ordem Constitucional de 1988. Ao país cabe buscar soluções políticosociais conciliatórias nos termos de uma democracia-constitucional para que nos possam verter novamente para o caminho da fidúcia e da credibilidade. Porém a sociedade espera que os "traidores da pátria" restem punidos para dar-se o start de um novo início de uma nova história. Resta saber se sobrará alguém para iniciar esta nova história ao ser comprida em largas bases a persecução a todos "traidores da pátria" (SARMENTO, 2016, n.p.). (Grifos nossos)

Ademais, na vigência do legalismo exacerbado em que vivemos, temos de tomar muito cuidado até como nossa liberdade de expressão: aos intervencionistas, vale lembrar que defender golpe de Estado, a se analisar o modo como está sendo realizada tal defesa, pode ser atitude classificada como crime punido pela Lei de Segurança Nacional (Lei Federal n. ${ }^{\circ}$ 7.170/1983) ou pelo próprio Código Penal, verbi gratia no caso da apologia ao crime, artigo 287.

A corrupção é uma escolha, uma possibilidade e não uma obrigatoriedade! Oxalá que mudanças ocorram no futuro desta nação antes do exício da esperança de seu povo por melhores condições de vida. Os nossos representantes agem alieno nomine e, ao agirem em nosso nome, devem nos respeitar, fazer o que for sempre melhor para todos nós, para o bem da coletividade.

Nesse caminhar, na melhor e mais prudente interpretação, a Constituição Federal de 1988 e regramentos inferiores sobre o tema "intervenção militar" não permitem um governo nacional militar provisório, sendo as Forças Armadas obedientes ao presidente da República e com permissão para atuarem apenas em intervenções específicas, em Estados ou municípios, para garantir a lei e a ordem. Assim, é possível uma "intervenção militar" do ponto de vista prático, mas impossível e inaceitável com base na lei (formalmente). Se houver em algum momento, torçamos para intervenções de organismos 
internacionais, como a Organização dos Estados Americanos e a Organização das Nações Unidas, a fim de que nossos direitos humanos sejam protegidos.

\section{REFERÊNCIAS BIBLIOGRÁFICAS}

BRASIL. Constituição da República Federativa do Brasil de 1988. Brasília: Congresso Nacional, 1988. Disponível em:

<http://www.planalto.gov.br/ccivil_03/constituicao/constituicaocompilado.htm>. Acesso em: 10 fev. 2018.

. Decreto n. ${ }^{\circ} 3.897$, de 24 de agosto de 2001. Brasília: Presidência da República, 2001.

Disponível em: <http://www.planalto.gov.br/ccivil_03/decreto/2001/d3897.htm>. Acesso em: 10 fev. 2018.

. Decreto-lei 2.848, de 7 de dezembro de 1940 (Código Penal). Rio de Janeiro: Presidência da República, 1940. Disponível em: <http://www.planalto.gov.br/ccivil_03/decreto-

lei/Del2848compilado.htm>. Acesso em: 10 fev. 2018.

. STF. Habeas Corpus número 98.237, j. 15-12-2009, 2a T, DJE de 6-8-2010. Disponível em: $\langle$ http://www.prerrogativas.org.br/Content/pdf/doc\%203.\%20hc\%2098.237.pdf >. Acesso em: 10 fev. 2018.

BRASIL 247. Comandante do Exército: “é lamentável clamor por intervenção militar”. BRASIL 247, 2016. Disponível em: <https://www.brasil247.com/pt/247/brasil/221764/comandante-doex\%c3\%a9rcito-\%e2\%80\%9c\%c3\%89-lament\%c3\%a1vel-clamor-por-interven\%c3\%a7\%c3\%a3omilitar\%e2\%80\%9d.htm>. Acesso em: 10 fev. 2018.

CAPANEMA JÚNIOR, José Alves. Possibilidade jurídica de intervenção militar. JusNavegandi, 2016. Disponível em: <https://jus.com.br/artigos/54490/possibilidade-juridica-de-intervencaomilitar>. Acesso em: 10 fev. 2018.

EL PAÍS BRASIL. Governo, Exército e Ministério Público não atuam contra general que defende a intervenção militar. Notícia Online, 2017. Disponível em:

<https://brasil.elpais.com/brasil/2017/09/19/politica/1505775429_803723.html>. Acesso em: 10 fev. 2018.

FERREIRA, Deybiane Francielly Santos. Intervenção militar na Constituição Federal de 1988.

ANAIS do I Congresso Norte Mineiro de Direito Constitucional, Montes Claros, MG, p. 1-7, 2015. Disponível em: <http://minascongressos.com.br/direitoconstitucional/x5.pdf>. Acesso em: $10 \mathrm{fev}$. 2018.

FOLHA DE SÃO PAULO. General fala em intervenção se Justiça não agir contra corrupção. Notícia Online, 2017. Disponível em: <http://www1.folha.uol.com.br/poder/2017/09/1919322-general-doexercitoameaca-impor-solucao-para-crise-politica-no-pais.shtml>. Acesso em: 10 fev. 2018. 
MENEZES, Alfredo da Mota. Momento brasileiro: do fim do regime militar à eleição de Lula. Rio de Janeiro: Gryphus, 2006.

MSN NOTÍCIAS. 'Exército é o mesmo de 1964, mas circunstâncias mudaram', diz comandante sobre pedidos de intervenção militar. Notícia Online, 2017. Disponível em:

<https://www.msn.com/ptbr/noticias/brasil/ex\%C3\%A9rcito-\%C3\%A9-o-mesmo-de-1964-mascircunst $\% \mathrm{C} 3 \% \mathrm{~A} 2$ ncias-mudaram-diz-comandante-sobre-pedidosdeinterven\%C3\%A7\%C3\%A3omilitar/arBBEVpgI?li=AAggXC1\&ocid=mailsignout $>$. Acesso em: 10 fev. 2018.

OLIVEIRA, Luciano. Ditadura militar, tortura e história: A "vitória simbólica" dos vencidos. Revista Brasileira de Ciências Sociais, n. 75, v. 26, p. 1-25, 2011. Disponível em:

<http://www.scielo.br/pdf/rbcsoc/v26n75/01.pdf >. Acesso em: 10 fev. 2018.

O GLOBO. General fala em possibilidade de Exército 'impor solução' para crise. Notícia Online, 2017. Disponível em: <https://oglobo.globo.com/brasil/general-fala-em-possibilidade-de-exercitoimpor-solucao-para-crise-21835609>. Acesso em: 10 fev. 2018.

PRIORI, A., et al. A Ditadura Militar e a violência contra os movimentos sociais, políticos e culturais. História do Paraná: séculos XIX e XX [online], Maringá, p. 199-213, 2012. Disponível em: <http://books.scielo.org/id/k4vrh/pdf/priori-9788576285878-15.pdf〉. Acesso em: 10 fev. 2018.

SARMENTO, Leonardo. Intervenção Militar Constitucional para restabelecimento da ordem? Possível? Um amplo debate Jurídico e político-sociológico. JusBrasil, 2016. Disponível em: <https://leonardosarmento.jusbrasil.com.br/artigos/341723771/intervencao-militar-constitucionalpara-restabelecimento-da-ordem-possivel-um-amplo-debate-juridico-e-politico-sociologico〉. Acesso em: 10 fev. 2018.

SILVA, Fernando Carlos Santos da. Aspectos legais do emprego do exército na garantia da lei e da ordem. Âmbito Jurídico, Rio Grande do Norte, IX, n. 30, jun, 2006. Disponível em: <http://www.ambitojuridico.com.br/site/index.php?n_link=revista_artigos_leitura\&artigo_id=1179>. Acesso em: 10 fev. 2018.

UOL NOTÍCIAS. Comandante diz que Exército não punirá general que defendeu intervenção militar. Notícia Online, 2017. Disponível em: $<$ https://noticias.uol.com.br/politica/ultimasnoticias/2017/09/20/comandante-do-exercito-diz-quenao-havera-punicao-a-general-por-defesa-de-intervencao-militar.htm>. Acesso em: 10 fev. 2018.

ZAPATER, Maíra. Intervenção Militar Constitucional: o perigo das versões apócrifas da Constituição. Carta Capital, 2015. Disponível em: $<$ http://justificando.cartacapital.com.br/2015/07/10/intervencao-militar-constitucional-o-perigo-dasversoes-apocrifas-da-constituicao/>. Acesso em: 10 fev. 2018. 